\title{
Effects of physical exercise on cognitively impaired older adults: a systematic review and meta-analysis of randomized control trials
}

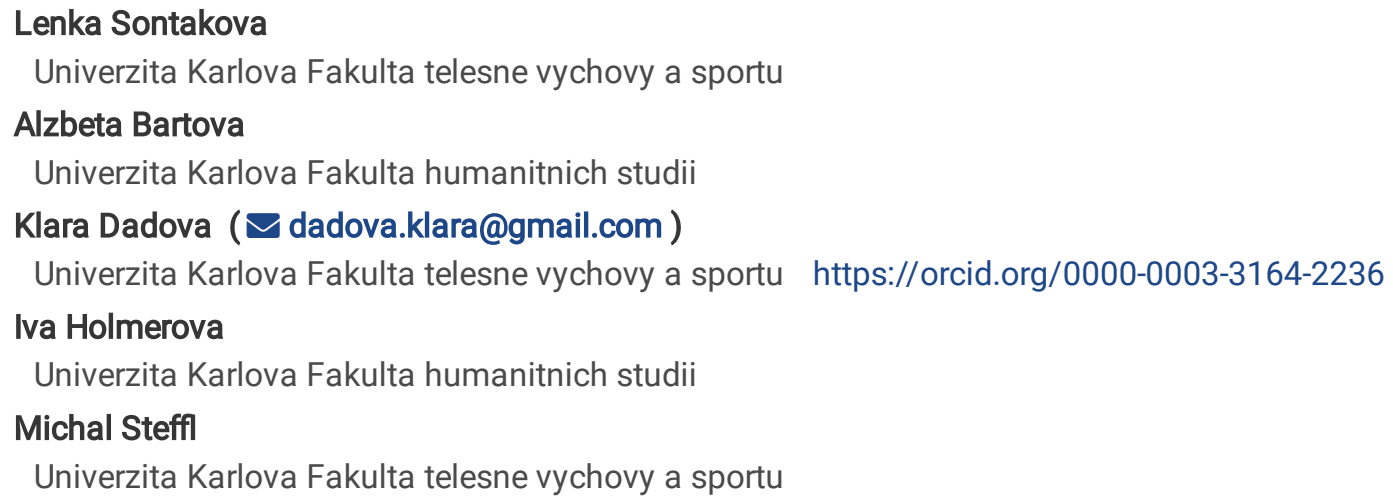

\section{Research article}

Keywords: Physical activity, Dementia, Aging, Meta-analysis, Aerobic exercise, Cognitive function

Posted Date: April 28th, 2020

DOl: https://doi.org/10.21203/rs.3.rs-15634/v2

License: (c) This work is licensed under a Creative Commons Attribution 4.0 International License. Read Full License 


\section{Abstract}

Objectives: The main aim of this study was to compare the effects of different physical activities on cognitive functions in older adults divided according to cognitive impairment levels.

Methods: We searched Web of Science, Scopus, and PubMed for randomized control trials (RCT). A standardized mean difference (SMD) of the pre-post intervention score of global cognitive function tests was calculated by the random model in the Cochrane meta-analyses for people with cognitive impairment generally and across three levels - mild, mild to moderate, and moderate to severe cognitive impairment separately. Additionally, an unstandardized coefficient beta (B) was calculated in generalized linear models to estimate the effects of exercise, cognitive impairment severity, age, female ratio, length of intervention, and time of exercise a week on the global cognitive function.

Results: Data from 26 studies involving 1,137 participants from intervention groups and 1,187 participants from control groups were analyzed. Physical exercise had a positive effect on cognitive functions in people across all levels of cognitive impairments SMD (95 $\%$ confidence interval $[\mathrm{Cl}])=1.19(0.77-1.62)$; however, heterogeneity was considerably high $\mathrm{I}^{2}=95 \%$. Aerobic $(\mathrm{B}=8.881)$ and resistance exercise $(B=4.464)$ was significantly associated with better results in global cognitive functions when compared to active control. A higher number of female participants in intervention groups had a statistically significant effect on the global cognitive function $(B=0.229)$.

Conclusions: Physical exercise was associated with cognitive function improvement in older people with cognitive impairments. Aerobic exercise was more strongly associated than resistance exercise to combat cognitive decline.

\section{Background}

The number of older adults with dementia is on the rise due to global population ageing. Current estimates suggest that more than 131.5 million people will be affected by dementia by the year 2050 [1]. Dementia is generally characterized by a progressive decline in cognitive and physical functions, often leading to a loss of independence and in some cases, institutionalization [2]. Thus, dementia impacts not only the daily lives of individuals diagnosed with the condition but also their families and broader society.

During the past two decades, epidemiological research has highlighted the link between modifiable lifestyle factors and cognitive function. For example, current evidence has demonstrated that a physically active lifestyle may help to delay the onset of cognitive decline and slow down disease progression [3], and physically active individuals have been shown to have a smaller risk of developing dementia or mild cognitive impairment than those who do not take part in any regular physical activity [4]. Moreover, results from several prospective studies have shown that exercise and physical fitness seem to have a positive effect on brain health $[5,6]$. In particular, it has been demonstrated that regular physical activity in mid-life is associated with a lower risk of dementia in later life [7], as well as that one of the most effective protections against neurodegenerative or vascular dementia is to be sufficiently physically active from mid-life [3]. In addition, it is now well known that exercise interventions increase the functional performance and activities of daily living in patients with cognitive impairments $[8,9,10,11,12]$. A positive effect of physical exercise on global cognition in individuals with mild cognitive impairments was partly confirmed $[13,14,15,16,17,18]$. Nevertheless, the effects of exercise on global cognitive function in people taking into account the level of cognitive impairment has still not been clearly elucidated. Likewise, the effects of aerobic and resistance exercise require further investigations too.

Therefore, the main aim of this study was to generally analyze the effects of exercise on cognitive functions in older adults divided according to cognitive impairment severity, taking into consideration the effects of resistance exercise and aerobic exercise separately. Additionally, we aimed to investigate the association between selected factors including the passive or active control, cognitive impairment severity, age, sex, frequency of exercise per week, and length of interventions on global cognitive function. We hypothesized that there exists a difference between aerobic and resistance exercise in terms of the effect on cognitive functions and that the effect might vary across different levels of cognitive impairment. We also hypothesized that different activity programs in control groups might influence the results. For example, a social program without physical activities may be beneficial for older adults with cognitive impairment. We also assumed that social or education activities in control groups might be more helpful against the cognitive decline rather than inactivity in passive control groups.

\section{Methods}

Page 2/18 
This study assessed the effects of physical exercise programs on people with cognitive impairment. It is reported in accordance with the Preferred Reporting Items for Systematic Reviews and Meta-Analyses (PRISMA) statement [19]. A compiled PRISMA checklist is included in Table 1.

Table 1 Checklist of items to include when reporting a systematic review or meta-analysis 


\begin{tabular}{|c|c|c|c|}
\hline Section/topic & \# & Checklist item & $\begin{array}{l}\text { Reported } \\
\text { on page } \\
\#\end{array}$ \\
\hline \multicolumn{4}{|l|}{ TITLE } \\
\hline Title & 1 & Identify the report as a systematic review, meta-analysis, or both. & 2 \\
\hline \multicolumn{4}{|l|}{ ABSTRACT } \\
\hline $\begin{array}{l}\text { Structured } \\
\text { summary }\end{array}$ & 2 & $\begin{array}{l}\text { Provide a structured summary including, as applicable: background; objectives; data sources; study eligibility } \\
\text { criteria, participants, and interventions; study appraisal and synthesis methods; results; limitations; conclusions } \\
\text { and implications of key findings; systematic review registration number. }\end{array}$ & $2-3$ \\
\hline \multicolumn{4}{|l|}{ INTRODUCTION } \\
\hline Rationale & 3 & Describe the rationale for the review in the context of what is already known. & $3-4$ \\
\hline Objectives & 4 & $\begin{array}{l}\text { Provide an explicit statement of questions being addressed with reference to participants, interventions, } \\
\text { comparisons, outcomes, and study design (PICOS). }\end{array}$ & 4 \\
\hline \multicolumn{4}{|l|}{ METHODS } \\
\hline $\begin{array}{l}\text { Protocol and } \\
\text { registration }\end{array}$ & 5 & $\begin{array}{l}\text { Indicate if a review protocol exists, if and where it can be accessed (e.g., Web address), and, if available, provide } \\
\text { registration information including registration number. }\end{array}$ & - \\
\hline $\begin{array}{l}\text { Eligibility } \\
\text { criteria }\end{array}$ & 6 & $\begin{array}{l}\text { Specify study characteristics (e.g., PICOS, length of follow-up) and report characteristics (e.g., years considered, } \\
\text { language, publication status) used as criteria for eligibility, giving rationale. }\end{array}$ & $5-6$ \\
\hline $\begin{array}{l}\text { Information } \\
\text { sources }\end{array}$ & 7 & $\begin{array}{l}\text { Describe all information sources (e.g., databases with dates of coverage, contact with study authors to identify } \\
\text { additional studies) in the search and date last searched. }\end{array}$ & $\begin{array}{l}\text { 6. Table } \\
2\end{array}$ \\
\hline Search & 8 & $\begin{array}{l}\text { Present full electronic search strategy for at least one database, including any limits used, such that it could be } \\
\text { repeated. }\end{array}$ & Table 2 \\
\hline $\begin{array}{l}\text { Study } \\
\text { selection }\end{array}$ & 9 & $\begin{array}{l}\text { State the process for selecting studies (i.e., screening, eligibility, included in systematic review, and, if } \\
\text { applicable, included in the meta-analysis). }\end{array}$ & 7, Fig 1 \\
\hline $\begin{array}{l}\text { Data collection } \\
\text { process }\end{array}$ & 10 & $\begin{array}{l}\text { Describe method of data extraction from reports (e.g., piloted forms, independently, in duplicate) and any } \\
\text { processes for obtaining and confirming data from investigators. }\end{array}$ & $7-8$ \\
\hline Data items & 11 & $\begin{array}{l}\text { List and define all variables for which data were sought (e.g., PICOS, funding sources) and any assumptions and } \\
\text { simplifications made. }\end{array}$ & - \\
\hline $\begin{array}{l}\text { Risk of bias in } \\
\text { individual } \\
\text { studies }\end{array}$ & 12 & $\begin{array}{l}\text { Describe methods used for assessing risk of bias of individual studies (including specification of whether this was } \\
\text { done at the study or outcome level), and how this information is to be used in any data synthesis. }\end{array}$ & $\begin{array}{c}7 \\
\text { Table } 4\end{array}$ \\
\hline $\begin{array}{l}\text { Summary } \\
\text { measures }\end{array}$ & 13 & State the principal summary measures (e.g., risk ratio, difference in means). & $7-8$ \\
\hline $\begin{array}{l}\text { Synthesis of } \\
\text { results }\end{array}$ & 14 & $\begin{array}{l}\text { Describe the methods of handling data and combining results of studies, if done, including measures of } \\
\text { consistency }\left(\mathrm{e} . \mathrm{g}, \mathrm{I}^{2}\right) \text { for each meta-analysis. }\end{array}$ & 8 \\
\hline $\begin{array}{l}\text { Risk of bias } \\
\text { across studies }\end{array}$ & 15 & $\begin{array}{l}\text { Specify any assessment of risk of bias that may affect the cumulative evidence (e.g., publication bias, selective } \\
\text { reporting within studies). }\end{array}$ & - \\
\hline $\begin{array}{l}\text { Additional } \\
\text { analyses }\end{array}$ & 16 & $\begin{array}{l}\text { Describe methods of additional analyses (e.g., sensitivity or subgroup analyses, meta-regression), if done, } \\
\text { indicating which were pre-specified. }\end{array}$ & 8 \\
\hline \multicolumn{4}{|l|}{ RESULTS } \\
\hline $\begin{array}{l}\text { Study } \\
\text { selection }\end{array}$ & 17 & $\begin{array}{l}\text { Give numbers of studies screened, assessed for eligibility, and included in the review, with reasons for } \\
\text { exclusions at each stage, ideally with a flow diagram. }\end{array}$ & $\begin{array}{l}\text { 8, Figure } \\
1\end{array}$ \\
\hline $\begin{array}{l}\text { Study } \\
\text { characteristics }\end{array}$ & 18 & $\begin{array}{l}\text { For each study, present characteristics for which data were extracted (e.g., study size, PICOS, follow-up period) } \\
\text { and provide the citations. }\end{array}$ & $\begin{array}{c}\text { Table 3, } \\
\quad 4\end{array}$ \\
\hline $\begin{array}{l}\text { Risk of bias } \\
\text { within studies }\end{array}$ & 19 & Present data on risk of bias of each study and, if available, any outcome level assessment (see item 12). & 9 \\
\hline $\begin{array}{l}\text { Results of } \\
\text { individual } \\
\text { studies }\end{array}$ & 20 & $\begin{array}{l}\text { For all outcomes considered (benefits or harms), present, for each study: (a) simple summary data for each } \\
\text { intervention group (b) effect estimates and confidence intervals, ideally with a forest plot. }\end{array}$ & Figure 2 \\
\hline $\begin{array}{l}\text { Synthesis of } \\
\text { results }\end{array}$ & 21 & Present results of each meta-analysis done, including confidence intervals and measures of consistency. & Figure 2 \\
\hline $\begin{array}{l}\text { Risk of bias } \\
\text { across studies }\end{array}$ & 22 & Present results of any assessment of risk of bias across studies (see Item 15). & - \\
\hline $\begin{array}{l}\text { Additional } \\
\text { analysis }\end{array}$ & 23 & $\begin{array}{l}\text { Give results of additional analyses, if done (e.g., sensitivity or subgroup analyses, meta-regression [see Item } \\
\text { 16]). }\end{array}$ & $9-10$ \\
\hline \multicolumn{4}{|l|}{ DISCUSSION } \\
\hline $\begin{array}{l}\text { Summary of } \\
\text { evidence }\end{array}$ & 24 & $\begin{array}{l}\text { Summarize the main findings including the strength of evidence for each main outcome; consider their relevance } \\
\text { to key groups (e.g., healthcare providers, users, and policy makers). }\end{array}$ & $10-12$ \\
\hline Limitations & 25 & $\begin{array}{l}\text { Discuss limitations at study and outcome level (e.g., risk of bias), and at review-level (e.g., incomplete retrieval } \\
\text { of identified research, reporting bias). }\end{array}$ & 12 \\
\hline Conclusions & 26 & $\begin{array}{l}\text { Provide a general interpretation of the results in the context of other evidence, and implications for future } \\
\text { research. }\end{array}$ & 13 \\
\hline
\end{tabular}


The PICO (population, intervention, comparisons, and outcomes) framework was used for framing the inclusion criteria (see below).

- Participants: people with a cognitive impairment being diagnosed with one of the standardized tools with a closed scale

- Intervention: activities requiring increased energy output excluding interventions combining both physical and cognitive training

- Comparisons: active or passive controls according to reported activities

- Outcomes: cognitive performance; focus on: type of exercise or control group activities, age and sex of participants, length of interventions, frequency of exercise, and severity of impairment

\section{Inclusion criteria for this study}

Based on the above-mentioned PICO framework, the following inclusion criteria were applied: only data from randomized trials (RCT) were used, and the participants had to be diagnosed with a cognitive impairment according to one of the standardized tools with a closed scale written in the English language. Following global cognitive function tests were considered appropriate: Cambridge Cognitive Examination (CAMCOG) [20], the Mini-Mental State Examination (MMSE) [21], the Rapid Evaluation of Cognitive Function (ERFC) [22], the Alzheimer Disease Assessment Scale-Cognitive Subscale (ADAS-Cog) [23], and the Montreal Cognitive Assessment (MoCA) [24].

Concerning the exercise programs, only exercise activities that required increased energy output without taking frequency or intensity into account were included. All intervention groups from studies with a combination of physical exercise and cognitive training were excluded. However, their control groups were included if they met our search criteria.

\section{Exercise intervention and control group classification}

Walking, stretching, toning, kinesiotherapeutic exercise, music-based dance therapy, ergometer cycling, as well as generally specified "aerobic exercise" were classed as aerobic exercise. When the intervention program included high-intensity functional exercise, strengthening exercise with own body weight, or exercise with dumbbells, we classed it as resistance exercise.

According to the activities that were prescribed, we divided the control groups into two categories - active and passive control groups. All the control groups with activities that could have potentially been beneficial for cognitive functions (for example, attention-control educational programs, social visits, or recreational activities such as card playing or home craftwork) were categorized as the active control groups. Control groups asked to maintain their usual activities were categorized as the passive control groups.

We also analysed information about the length of intervention, the duration of exercise per week, and female ratios.

\section{Search strategy}

The analysis was conducted by identifying relevant papers referenced in the Web of Science, Scopus, and PubMed. Search terms used in all databases are presented in Table 2.

Table 2 Search results in electronic databases

\begin{tabular}{llc}
\hline DATABASE & KEY & NUMBER \\
\hline Web of & TITLE: (dementia) OR TITLE: ("Alzheimer disease") OR TITLE: ("cognitive function") OR TITLE: ("cognitive impairment") \\
Science & AND TITLE: ("physical activity") OR TITLE: (exercise) OR TITLE: (training) AND TOPIC: (randomized) OR TOPIC: (trial)
\end{tabular}

Scopus ( ( TITLE ( dementia) OR TITLE ( "Alzheimer disease" ) OR TITLE ( "cognitive impairment" ) OR TITLE ( "cognitive function" ) ) ) AND ( ( TITLE ( "physical activity" ) OR TITLE ( exercise ) OR TITLE ( training ) ) ) AND (( TITLEABS-KEY ( randomized) OR TITLE-ABS-KEY ( trial ) )) [Title]))) AND (((("physical activity" [Title]) OR exercise[Title]) OR training[Title]))) AND ((randomized[Title/Abstract]) OR trial[Title/Abstract]) 


\section{Data extraction and quality assessment}

All potential papers were first downloaded into EndNote. Then, our three reviewing authors (LS, AT, and MS) deleted all the duplicates and scanned the titles and abstracts of the papers in order to identify studies that had the potential to meet the eligibility criteria. Full texts were subsequently assessed for eligibility. Any disagreements among the reviewers $(K D$, and $I H)$ were resolved through discussions. We used the Physiotherapy Evidence Database (PEDro) scale to assess the methodological quality of the included studies [25].

We collected the following data for both the exercise groups and control groups separately: baselines and after intervention means with 95\% confidence interval (CI) and/or standard deviation (SD); and if described, also the mean of post-pre intervention score with SD or $95 \% \mathrm{Cl}$ were collected. Additionally, for factors or covariates for general linear models, we collected information about the type of exercise or control group activities, age of participants, sex of participants, length of interventions, and frequency of exercise.

\section{Cognitive impairment classification}

We divided the participants into three categories according to the level of their cognitive impairment: mild, mild to moderate, and moderate to severe impairment. In the classification, we used a $95 \% \mathrm{Cl}$ of the baseline mean in the standardized 100 points scale. Mild cognitive impairment = the lower $95 \% \mathrm{Cl}>65.0$ points, mild to moderate cognitive impairment $=$ the lower $95 \% \mathrm{Cl}>57$ to points, and moderate to severe impairment $=$ the upper $95 \% \mathrm{Cl}<60$ points. This division was in concordance with the standard diagnostic of cognitive impairment according to MMSE [26]. We could say with $95 \%$ certainty that in the mild impairment group there were not participants with less than 20.1 points, in the mild to moderate impairment group there were not participants with less than 17.1 points and in the moderate to severe impairment group, there were not any participants with higher than 18 points.

\section{Data analysis}

The sample size and mean post-pre intervention score with standard deviation (SD) from intervention as well as control groups were used to calculate the standardized mean differences (SMD). The random effect models were used for all the analyses [27]. To assess the heterogeneity $\mathrm{I}^{2}$ was considered. A rough guide to the interpretation of $\mathrm{I}^{2}$ is as follows: 0 to $40 \%$ might not be important, $30 \%$ to $60 \%$ may represent moderate heterogeneity, $50 \%$ to $90 \%$ may represent considerable heterogeneity, and $75 \%$ to $100 \%$ represents substantial heterogeneity [28]. Additionally, we standardized all the mean of the baseline score and post-pre intervention score from all the groups separately onto the 100 points scale. Then generalized linear models were used to estimate the influences of selected factors and covariates to the standardized post-pre intervention score as the continual dependent variable. We calculated an unstandardized coefficient beta (B), standard error (SE) and $95 \% \mathrm{Cl}$. B represents the amount by which dependent variable changes if we change independent variable by one unit keeping other independent variables constant. If $95 \% \mathrm{Cl}$ does not cross the 0 then the result is statistically significant. Statistics were calculated using RevMan 5.3 and IBM SPSS Statistics 24.

\section{Results}

\section{Description of studies}

We included 26 randomized controlled trials in the final analysis out of the 785 publications resulting from the database search. These were controlled trials on physical activity and its effect on cognitive performance in people with cognitive impairment. Figure 1 shows the PRISMA flow diagram. Across the studies, we extracted data from 2,324 participants, all being over 50 years of age (60.1 $\%$ females). The standardized baseline mean of cognitive function tests in all the groups included was $66.9(95 \% \mathrm{Cl} 62.3-71.5)$, which corresponded to 20.1 (95\% Cl 18.7-24.5) points of the MMSE classed as a mild to moderate cognitive impairment according to the standard interpretation of MMSE [26]. Interventions were mostly aerobic exercise and walking, and the amount of exercise varied between 60 minutes to 420 minutes per week. The shortest duration period of the intervention was 6 weeks, and the longest was 60 weeks. As the main outcome, the following were used: 21x MMSE [21], 1x CAMCOG [20], 1x MoCA [24], 1x ERFC [22], and 2x ADAS-Cog [23]. 16 out of the 26 control groups took part in additional activities such as education, one-to-one conversation or recreational activities. The other participants in control groups were instructed to maintain their normal physical activities, or they 
had standard care in nursing homes. 10 out of 24 intervention groups presented a statistical beneficial effect while only 2 presented a significant harmful effect. There was no significant effect found in 12 studies involving intervention groups. While more than onethird of the interventions were beneficial, 14 out of 26 controls showed significantl decrease in cognitive functions. Descriptions of intervention and control groups included in the review are presented in Table $3[29,30,31,32,33,34,35,36,37,38,39,40,41,42,43$, $44,45,46,47,48,49,50,51,52,53,54]$. All of the included studies were considered to have had a good methodological quality, scoring between 7 and 9 points according to the PEDro. The methodological quality of the included studies according to the PEDro scale is presented in Table 4.

Table 3 Studies included in the analyses 


\begin{tabular}{|c|c|c|c|c|c|}
\hline Study & Main parts of interventions & $\begin{array}{l}\text { Group } \\
\text { size }\end{array}$ & Settings & $\begin{array}{l}\text { Main } \\
\text { Outcome }\end{array}$ & $\begin{array}{l}\text { Statistically } \\
\text { significant } \\
\text { effect }\end{array}$ \\
\hline $\begin{array}{l}\text { Arcoverde, } \\
2014\end{array}$ & 30 min treadmill walking at $60 \%$ of $\mathrm{VO}_{2}$ max; $2 \mathrm{x}$ a week; 16 weeks & 10 & $\mathrm{H}$ & CAMCOG & Beneficial \\
\hline Bademli, 2018 & 40 min aerobics exercise $4 \mathrm{x}$ a week and 40 min walking $3 \mathrm{x}$ a week; 20 weeks & 30 & $\mathrm{~N}$ & MMSE & Beneficial \\
\hline \multirow[t]{2}{*}{ Bossers, 2015} & 30 min walking; 36 individualized sessions in 9 weeks & 36 & $\mathrm{~N}$ & MMSE & No \\
\hline & $\begin{array}{l}30 \text { min of strength sessions or walking sessions; } 18 \text { and } 18 \text { individualized sessions in } 9 \\
\text { weeks }\end{array}$ & 37 & $\mathrm{~N}$ & MMSE & No \\
\hline Cancela, 2016 & 15 min cycling ergometer; $7 x$ a week; 60 weeks & 51 & $\mathrm{H}$ & MMSE & No \\
\hline Holthoff, 2015 & $\begin{array}{l}30 \text { min home-based motor-assisted or active resistive training of the legs; } 3 \mathrm{x} \text { a week; } 12 \\
\text { weeks }\end{array}$ & 15 & $\mathrm{H}$ & MMSE & No \\
\hline Hong, 2018 & $\begin{array}{l}60 \text { min exercise with an elastic band at } 15 \text {-repetition maximum ( } 65 \% \text { of } 1 \mathrm{RM}) ; 2 \mathrm{x} \text { a week; } \\
12 \text { weeks }\end{array}$ & 10 & $\mathrm{H}$ & MoCA & No \\
\hline $\begin{array}{l}\text { Christofoletti, } \\
2008\end{array}$ & 60 min kinesiotherapeutic exercises; 3x a week; 6 months & 17 & $\mathrm{~N}$ & MMSE & Beneficial \\
\hline Kemoun, 2010 & 60 min articular mobilization, muscle stimulation, and walking; 3x a week; 15 weeks & 16 & $\mathrm{~N}$ & ERFC & Beneficial \\
\hline Kwak, 2008 & 30 - 60 min chair exercises max. $60 \% \mathrm{VO}_{2}$ max; $2-3 \mathrm{x}$ a week; 12 months & 15 & $\mathrm{H}$ & MMSE & Beneficial \\
\hline Lam, 2015 & $\begin{array}{l}60 \text { min stretching and toning exercise, one mind body exercise (e.g. Tai Chi) and one } \\
\text { aerobic exercise session (e.g. static bicycle riding); } 3 \mathrm{x} \text { a week; } 12 \text { months }\end{array}$ & 147 & $\mathrm{H}$ & MMSE & No \\
\hline Lamb, 2018 & $\begin{array}{l}70 \text { min aerobic and strengthening exercise program of moderate to high intensity; } 2 \mathrm{x} \text { a } \\
\text { week; } 16 \text { weeks }\end{array}$ & 298 & $\mathrm{C}$ & $\begin{array}{l}\text { ADAS- } \\
\text { Cog }\end{array}$ & No \\
\hline Langoni, 2018 & $\begin{array}{l}60 \text { min exercise with elastic bands, balls, ankle weights, own body weight, and } \\
\text { dumbbells; } 2 \mathrm{x} \text { a week; } 24 \text { weeks }\end{array}$ & 26 & $\mathrm{H}$ & MMSE & Beneficial \\
\hline $\begin{array}{l}\text { Lautenschlager, } \\
2008\end{array}$ & $\begin{array}{l}50 \text { min walking, light strength training exercise, circuit gym exercise; 3x a week; } 24 \\
\text { weeks }\end{array}$ & 85 & $\mathrm{H}$ & $\begin{array}{l}\text { ADAS- } \\
\text { Cog }\end{array}$ & No \\
\hline Miu, 2008 & $\begin{array}{l}60 \text { min aerobic exercise training with treadmill, bicycle, arm ergometry and flexibility } \\
\text { exercises; } 2 \mathrm{x} \text { a week; } 12 \text { weeks }\end{array}$ & 36 & $\mathrm{H}$ & MMSE & Harmful \\
\hline Muscari, 2009 & $\begin{array}{l}60 \text { min cycle ergometer, treadmill and free-body activity at intensity } 70 \% \text { of maximal } \\
\text { heart rate; } 3 \mathrm{x} \text { a week; } 12 \text { months }\end{array}$ & 60 & $\mathrm{C}$ & MMSE & No \\
\hline Toots, 2017 & $\begin{array}{l}40 \text { min high-intensity functional exercises performed in weight bearing positions; } 5 \mathrm{x} \text { per } \\
\text { two-week; } 16 \text { weeks }\end{array}$ & 93 & $\mathrm{~N}$ & MMSE & Harmful \\
\hline $\begin{array}{l}\text { Van de Winckel, } \\
2004\end{array}$ & 30 min music-based dance therapy and a conversational session; 7x a week; 6 weeks & 15 & Hos & MMSE & No \\
\hline \multirow[t]{2}{*}{ Varela, 2012} & 30 min exercise on $60 \%$ of participant's heart rate reserve; $3 \mathrm{x}$ a week; 12 weeks & 16 & $\mathrm{~N}$ & MMSE & Beneficial \\
\hline & 30 min exercise on $40 \%$ of participant's heart rate reserve; $3 \mathrm{x}$ a week; 12 weeks & 17 & $\mathrm{~N}$ & MMSE & Beneficial \\
\hline $\begin{array}{l}\text { Venturelli, } \\
2011\end{array}$ & 30 min walking; $4 \mathrm{x}$ a week; 6 months & 12 & $\mathrm{~N}$ & MMSE & No \\
\hline $\begin{array}{l}\text { Vreugdenhil, } \\
2012\end{array}$ & $\begin{array}{l}30 \text { min upper and lower body strength and balance training in addition to at least } 30 \\
\text { minutes of brisk walking; daily; } 16 \text { weeks }\end{array}$ & 20 & $\mathrm{C}$ & MMSE & Beneficial \\
\hline $\begin{array}{l}\text { Williamson, } \\
2009\end{array}$ & $\begin{array}{l}60 \text { min combination of aerobic, strength, balance, and flexibility exercises; } 3 x \text { a week; } 12 \\
\text { months }\end{array}$ & 50 & $\mathrm{H}$ & MMSE & No \\
\hline Yang, 2015 & 40 min cycling training at $70 \%$ of maximal intensity; $3 \mathrm{x}$ a week; 12 weeks & 25 & Hos & MMSE & Beneficial \\
\hline
\end{tabular}

\section{Control groups}

\begin{tabular}{|c|c|c|c|c|c|}
\hline Study & Activities & $\begin{array}{l}\text { Group } \\
\text { size }\end{array}$ & Settings & $\begin{array}{l}\text { Main } \\
\text { Outcome }\end{array}$ & $\begin{array}{l}\text { signinicant } \\
\text { effect }\end{array}$ \\
\hline $\begin{array}{l}\text { Arcoverde, } \\
2014\end{array}$ & - & 10 & $\mathrm{H}$ & CAMCOG & Harmful \\
\hline Bademli, 2018 & - & 30 & $\mathrm{~N}$ & MMSE & Harmful \\
\hline Bossers, 2015 & Four social visits each week & 36 & $\mathrm{~N}$ & MMSE & No \\
\hline Burgener, 2008 & Attention-control educational programs & 19 & $\mathrm{H}$ & MMSE & No \\
\hline Cancela, 2016 & Recreational activities - card-playing, reading, craftwork & 63 & $\mathrm{H}$ & MMSE & Harmful \\
\hline Holthoff, 2015 & - & 15 & $\mathrm{H}$ & MMSE & No \\
\hline Hong, 2018 & - & 12 & $\mathrm{H}$ & MoCA & No \\
\hline $\begin{array}{l}\text { Christofoletti, } \\
2008\end{array}$ & - & 20 & $\mathrm{~N}$ & MMSE & No \\
\hline Kemoun, 2010 & $\begin{array}{l}\text { Manual and intellectual activities organized by the nursing home (pottery, painting, soft } \\
\text { gymnastics, outings, etc.) }\end{array}$ & 15 & $\mathrm{~N}$ & ERFC & Harmful \\
\hline Kwak, 2008 & - & 15 & $\mathrm{H}$ & MMSE & No \\
\hline Lam, 2015 & At least three one-hour social activity sessions per week & 131 & $\mathrm{H}$ & MMSE & No \\
\hline
\end{tabular}


Langoni, 2018 -

Lautenschlager, Educational material about memory loss, stress management, healthful diet, alcohol

$85 \mathrm{H}$

MMSE

Harmful

2008 consumption, and smoking

Miu, 2008

20

Muscari, 2009 Educational materials about suggestions to improve lifestyle, including individualized

$49 \quad \mathrm{H}$

$60 \quad \mathrm{C}$

ADASHarmful self-administered programs to increase physical activity

Shimada, 2017 90-minute health promotion classes thrice over the 40-week trial period

Suzuki, 20132 education classes about health promotion during the 6-month study period

Suzuki, 20123 education classes about health promotion during the 12-month study period Participants conversed, sang, listened to music or readings, and/or looked at pictures and objects

Toots, 2017

Van de Winckel, One-to-one conversation

$154+2$

MMSE

MMSE Harmful

2004

Varela, 2012 Recreational activities - playing cards, reading newspapers, handicrafts

\begin{tabular}{llll}
154 & C & MMSE & Harmful \\
\hline 50 & C & MMSE & No \\
25 & C & MMSE & No \\
93 & N & MMSE & Harmful \\
& & &
\end{tabular}

Venturelli, Organized activities like bingo, patchwork sewing, and music therapy

10 Hos MMSE No

2011

Vreugdenhil,

$15 \quad \mathrm{~N} \quad$ MMSE Harmful

2012

Williamson, 2009 Health education - a session per week included health topics relevant to older adults

20

C

MMSE Harmful

Yang, 2015 such as nutrit
different ages

52

Health education

25

Hos

MMSE

Harmful

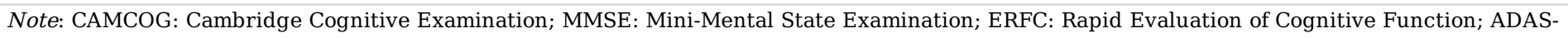

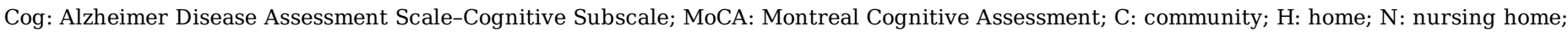
Hos: hospital

Table 4 PEDro scores of the included studies 


\begin{tabular}{|c|c|c|c|c|c|c|c|c|c|c|c|c|}
\hline Study & $\begin{array}{l}\text { Eligibility } \\
\text { criteria }\end{array}$ & Randomization & $\begin{array}{l}\text { Concealed } \\
\text { allocation }\end{array}$ & $\begin{array}{l}\text { Similar } \\
\text { group } \\
\text { baselines }\end{array}$ & $\begin{array}{l}\text { Blinding } \\
\text { of all } \\
\text { subjects }\end{array}$ & $\begin{array}{l}\text { Blinding } \\
\text { of all } \\
\text { therapists }\end{array}$ & $\begin{array}{l}\text { Blinding } \\
\text { of all } \\
\text { assessors }\end{array}$ & $\begin{array}{l}\text { Drop } \\
\text { out } \\
< \\
15 \%\end{array}$ & $\begin{array}{l}\text { Intention- } \\
\text { to-treat } \\
\text { method }\end{array}$ & $\begin{array}{l}\text { Statistical } \\
\text { between- } \\
\text { group } \\
\text { comparison }\end{array}$ & $\begin{array}{l}\text { Point } \\
\text { measures } \\
\text { and } \\
\text { measures } \\
\text { of } \\
\text { variability }\end{array}$ & Score \\
\hline $\begin{array}{l}\text { Arcoverde, } \\
2014\end{array}$ & 1 & 1 & 1 & 1 & 1 & 0 & 0 & 1 & 1 & 1 & 1 & 9 \\
\hline Bademli, 2018 & 1 & 1 & 1 & 1 & 0 & 0 & 0 & 1 & 1 & 1 & 1 & 8 \\
\hline Bossers, 2015 & 1 & 1 & 1 & 1 & 0 & 0 & 0 & 1 & 1 & 1 & 1 & 8 \\
\hline Burgener, 2008 & 1 & 1 & 1 & 1 & 0 & 0 & 0 & 1 & 1 & 1 & 1 & 8 \\
\hline Cancela, 2016 & 1 & 1 & 1 & 1 & 0 & 0 & 1 & 0 & 1 & 1 & 1 & 8 \\
\hline Holthoff, 2015 & 1 & 1 & 1 & 1 & 0 & 0 & 0 & 1 & 1 & 1 & 1 & 8 \\
\hline Hong, 2018 & 1 & 1 & 1 & 1 & 0 & 0 & 0 & 0 & 1 & 1 & 1 & 7 \\
\hline $\begin{array}{l}\text { Christofoletti, } \\
2008\end{array}$ & 1 & 1 & 1 & 1 & 0 & 0 & 1 & 1 & 1 & 1 & 1 & 9 \\
\hline Kemoun, 2010 & 1 & 1 & 1 & 1 & 0 & 0 & 0 & 0 & 1 & 1 & 1 & 7 \\
\hline Kwak, 2008 & 1 & 1 & 1 & 1 & 0 & 0 & 0 & 1 & 1 & 1 & 1 & 8 \\
\hline Lam, 2015 & 1 & 1 & 1 & 1 & 0 & 0 & 0 & 1 & 1 & 1 & 1 & 8 \\
\hline Lamb, 2018 & 1 & 1 & 1 & 0 & 0 & 0 & 0 & 1 & 1 & 1 & 1 & 7 \\
\hline Langoni, 2018 & 1 & 1 & 1 & 1 & 1 & 0 & 0 & 1 & 1 & 1 & 1 & 9 \\
\hline $\begin{array}{l}\text { Lautenschlager, } \\
2008\end{array}$ & 1 & 1 & 1 & 1 & 1 & 0 & 0 & 1 & 1 & 1 & 1 & 9 \\
\hline Miu, 2008 & 1 & 1 & 1 & 0 & 0 & 0 & 0 & 1 & 1 & 1 & 1 & 7 \\
\hline Muscari, 2009 & 1 & 1 & 1 & 1 & 0 & 0 & 0 & 1 & 1 & 1 & 1 & 8 \\
\hline Shimada, 2017 & 1 & 1 & 1 & 1 & 0 & 0 & 0 & 0 & 1 & 1 & 1 & 7 \\
\hline Suzuki, 2013 & 1 & 1 & 1 & 1 & 0 & 0 & 1 & 1 & 1 & 1 & 1 & 9 \\
\hline Suzuki, 2012 & 1 & 1 & 1 & 1 & 0 & 0 & 1 & 1 & 1 & 1 & 1 & 9 \\
\hline Toots, 2017 & 1 & 1 & 1 & 1 & 1 & 0 & 0 & 1 & 1 & 1 & 1 & 9 \\
\hline $\begin{array}{l}\text { Van de Winckel, } \\
2004\end{array}$ & 1 & 1 & 1 & 0 & 0 & 0 & 0 & 1 & 1 & 1 & 1 & 7 \\
\hline Varela, 2012 & 1 & 1 & 1 & 1 & 0 & 0 & 0 & 0 & 1 & 1 & 1 & 7 \\
\hline $\begin{array}{l}\text { Venturelli, } \\
2011\end{array}$ & 1 & 1 & 1 & 1 & 0 & 0 & 0 & 0 & 1 & 1 & 1 & 7 \\
\hline $\begin{array}{l}\text { Vreugdenhil, } \\
2012\end{array}$ & 1 & 1 & 1 & 1 & 0 & 0 & 1 & 1 & 1 & 1 & 1 & 9 \\
\hline $\begin{array}{l}\text { Williamson, } \\
2009\end{array}$ & 1 & 1 & 1 & 1 & 0 & 0 & 1 & 1 & 1 & 1 & 1 & 9 \\
\hline Yang, 2015 & 1 & 1 & 1 & 1 & 0 & 0 & 0 & 1 & 1 & 1 & 1 & 8 \\
\hline
\end{tabular}

\section{Exercise effect}

In general, physical exercise had a positive effect on cognitive functions in people with cognitive impairment SMD $(95 \% \mathrm{Cl})=1.19$ (0.77 - 1.62); however, heterogeneity was considerably high $\mathrm{I}^{2}=95 \%$. In separate groups according to the cognitive impairment severity, the only aerobic exercise had statistically significant effect SMD $(95 \% \mathrm{Cl})=2.42(0.86-3.99)$ in mild and $1.73(1.08-2.38)$ in moderate to severe impairment respective. Nevertheless, the heterogeneity was considerably high as well. A forest plot with a graphical representation of individual effects is presented in Figure 2.

In the generalized linear models, when we used the active control groups as a reference category, its change on the aerobic exercise group caused an increase in the post-pre intervention score estimate by more than 8 times $(B=8.881)$ and the change on resistance group by 4 times $(B=4.464)$, both significantly. When comparing passive groups to active groups there was found a negative trend for the passive controls, nevertheless, not significant. Cognitive impairment level, as well as age and length of intervention, were not significantly associated with the post-pre intervention score. The result of the generalized linear model of intervention and control groups together is presented in Table 5.

Table 5 Generalized linear model for both groups 


\begin{tabular}{|c|c|c|c|c|}
\hline & \multirow[t]{2}{*}{ B } & \multirow[t]{2}{*}{$\mathrm{SE}$} & \multicolumn{2}{|c|}{$95 \% \mathrm{CI}$} \\
\hline & & & Lower & Upper \\
\hline \multicolumn{5}{|l|}{ Physical activity } \\
\hline Aerobic exercise & 8.881* & 1.677 & 5.594 & 12.167 \\
\hline Resistance exercise & 4.464* & 1.779 & 0.978 & 7.951 \\
\hline Passive control & -0.170 & 1.839 & -3.774 & 3.434 \\
\hline Active control & $0^{\mathrm{a}}$ & & & \\
\hline \multicolumn{5}{|l|}{ Cognitive impairment } \\
\hline Mild to moderate & 2.519 & 2.163 & -1.720 & 6.758 \\
\hline Mild & 2.625 & 2.624 & -2.518 & 7.769 \\
\hline Moderate to severe & $0^{\mathrm{a}}$ & & & \\
\hline \multicolumn{5}{|l|}{ Length of intervention } \\
\hline Less than half a year & 2.750 & 1.487 & -0.163 & 5.663 \\
\hline More than half a year & $0^{\mathrm{a}}$ & & & \\
\hline Age & -0.146 & 0.214 & -0.565 & 0.274 \\
\hline
\end{tabular}

For the intervention groups, aerobic exercise was significantly strongly associated with better results in the post-pre intervention score estimate $(B=4.326)$ compared to resistance exercise. Shorter interventions had significantly better effect compared to the lengthier ones $(B=4.798)$. In addition, age played a significant negative role $(B=-0.708)$, and a higher number of women in intervention groups had a statistically significant effect as well $(B=0.229)$. Cognitive impairment level, as well as time of exercise weekly, were not significantly associated with the post-pre intervention score. The result of the generalized linear model of intervention groups separately is presented in Table 6.

Table 6 Generalized linear model for intervention groups

\begin{tabular}{|c|c|c|c|c|}
\hline & \multirow[t]{2}{*}{ B } & \multirow[t]{2}{*}{$\mathrm{SE}$} & \multicolumn{2}{|c|}{$95 \% \mathrm{CI}$} \\
\hline & & & Lower & Upper \\
\hline \multicolumn{5}{|l|}{ Physical activity } \\
\hline Aerobic exercise & $4.326 *$ & 1.730 & 0.936 & 7.716 \\
\hline Resistance exercise & $0^{\mathrm{a}}$ & & & \\
\hline \multicolumn{5}{|l|}{ Cognitive impairment } \\
\hline Mild to moderate & 1.974 & 2.751 & -3.430 & 7.365 \\
\hline Mild & 0.315 & 3.008 & -5.580 & 6.210 \\
\hline Moderate to severe & $0^{\mathrm{a}}$ & & & \\
\hline \multicolumn{5}{|l|}{ Length of intervention } \\
\hline Less than half a year & 4.798* & 1.867 & 1.129 & 8.449 \\
\hline More than half a year & $0^{\mathrm{a}}$ & & & \\
\hline \multicolumn{5}{|l|}{ Time a week } \\
\hline$>2$ hours & 0.118 & 1.989 & -4.017 & 3.780 \\
\hline$\leq 2$ hours & $0^{\mathrm{a}}$ & & & \\
\hline Age & $-0.708 *$ & 0.318 & -1.332 & -0.084 \\
\hline Female ratio & $0.229 *$ & 0.064 & 0.103 & 0.355 \\
\hline
\end{tabular}

\section{Discussion}

It is well-established that cognitive functions decline gradually over time as part of the natural ageing process [55]. The overall results of this meta-analysis indicate that physical exercise and specifically aerobic exercise may have the power to mitigate cognitive decline process even in people with cognitive impairment.

According to our results, aerobic exercise had twice higher impact on cognitive functions than resistance exercise when compared to active controls, and 4 times when compared only the intervention groups. Previous studies partly confirmed a positive effect of physical exercise on executive functions $[14,15]$, and global cognition $[16,17,18]$ in individuals with mild cognitive impairments. However, we found that aerobic exercise also had a statistically significant positive effect in moderate to severe cognitively impaired people. Probably the positive effect of aerobic exercise on brain health seems to lie in the proposed mechanisms behind aerobic 
exercise such as neovascularization, synaptogenesis and angiogenesis, hippocampal high-affinity choline uptake and upregulation of muscarinic receptor density, increasing of mitochondrial volume in Purkinje cells, inhibition of the apoptotic biochemical cascades, identified primarily through animal research $[56,57,58,59]$.

Moreover, a higher number of female participants in intervention groups had a positive effect on global cognitive function. This result could be explained by both different cognitive responses to exercise between men and women as well as by the different ratios in elderly females suffering dementia. As described by Baker et al. (2010), aerobic exercise improved performance on multiple tests of executive function, increased glucose disposal during the metabolic clamp, and reduced fasting plasma levels of insulin, cortisol, and brain-derived neurotrophic factor in women but not in men [60]. They also found that peak oxygen consumption was associated with improved executive function in women. It turns out that gender differences in cognitive functions can be related to the metabolic effects of physical activity. However, there are several other reasons that sex may influence trial results. For instance, women have a higher lifetime risk of dementia [61], greater vulnerability to certain risk factors such as sex specific chromosomes, APOE $\varepsilon 4$, sex differences in hormone levels etc. [62], and they demonstrate higher differential associations between biomarkers and cognitive impairment than men [63]. Moreover, there was a higher percentage of female participants in the intervention studies (19 of 24 intervention studies had a majority of female participants). One reason for this fact could be higher life expectancy in females [64] although the gender gap has been narrowing in Europe recently [65]. Another explanation could be greater adherence to health-related exercise programs in older women [66]. Thus, it would be of interest to explain which of the above-mentioned proposed factors is responsible for gender differences.

Studies included in this meta-analysis varied in terms of length of interventions. In fifteen studies, the duration of interventions was less than half a year, and in another nine, the duration of the interventions was for more than half a year. According to our analysis, it seems that the length of the intervention was associated with cognitive decline. We may hypothesize that this was probably caused by the natural ageing process. Surprisingly, the frequency of exercise per week did not play any significant role in global cognition.

It should be noted that several limitations are involved in this study. There was considerable heterogeneity in all the analyses. Unfortunately, it could not be controlled for by the sensitivity analysis otherwise more than half of the studies would have to be excluded. In fact, heterogeneity is a common problem when conducting meta-analyses on this topic [14, 18], so the standard approach is not always the best. Nevertheless, using general linear models involved some limitations too. For example, we used only individual standardized post-pre mean difference and not the total amplitude such as $95 \% \mathrm{Cl}$. Therefore, the statistical significance of individual studies could not be drawn. Moreover, it was almost impossible to create a category with similar cognitive impairment because it varied considerably among the studies. The same is true for exercise interventions because the interventions included many different activities with different durations and intensities.

\section{Conclusion}

Despite the numerous above-mentioned limitations this study has shown that physical exercise and especially aerobic exercise may have the power to influence cognitive functions in people with cognitive impairment. Such findings could have practical implications such as to recommend physical activity as a nonpharmacologic treatment to combat the progression of cognitive decline in patients with dementia. Future research based on longitudinal epidemiological studies is needed to confirm such findings further.

\section{List Of Abbreviations}

ADAS-Cog Alzheimer Disease Assessment Scale-Cognitive Subscale

B

CAMCOG Cambridge Cognitive Examination

$\mathrm{Cl} \quad$ Confidence Interval

ERFC Rapid Evaluation of Cognitive Function

MMSE Mini Mental State Examination 
MoCA Montreal Cognitive Assessment

PRISMA Preferred Reporting Items for Systematic Reviews and Meta-Analyses

PEDro Physiotherapy Evidence Database

RCT Randomized Control Trials

SE Standard Error

SMD Standardized Mean Difference

$\mathrm{VO}_{2} \max \quad$ the maximum amount of oxygen the body can utilize during a specified period of usually intense exercise.

WA Weighted Averages

\section{Declarations}

Our results have not been published previously and are not under submission elsewhere. Co-authors are cognizant of the submitted text and agree to its publication in BMC Public Health.

Ethics approval and consent to participate

N/A

Consent for publication

N/A

Availability of supporting data and material

The datasets used and/or analyzed during the current study are available from the corresponding author on reasonable request.

Competing interests

The authors declare that they have no competing interests.

Funding

This research was supported by the Alzheimer Endowment Fund - AVAST, the project Q41, the AZV research project NV18-09-00587 of the Ministry of Health and project SVV 260466.

The funding agencies played no role in study design, data collection and analysis, decision to publish, or preparation of the manuscript.

Authors' contribution

$\mathrm{LS}, \mathrm{AB}$, and MS have screened the literature and selected papers for inclusion in the review LS, MS, KD, and IH have contributed to data extraction. All authors read and approved the final manuscript.

Acknowledgements

N/A

\section{References}

1. Shah H, Albanese E, Duggan C, et al. Research priorities to reduce the global burden of dementia by 2025 . Lancet Neurol. 2016;15(12):1285-1294.

Page $13 / 18$ 
2. Winblad B, Amouyel P, Andrieu S, et al. Defeating Alzheimer's disease and other dementias: a priority for European science and society. Lancet Neurol. 2016;15(5):455-532.

3. Rolland Y, Abellan van Kan G, Vellas B. Physical activity and Alzheimer's disease: from prevention to therapeutic perspectives. J Am Med Dir Assoc. 2008;9(6):390-405.

4. Rockwood K, Middleton L. Physical activity and the maintenance of cognitive function. Alzheimers Dement. 2007;3(2 Suppl):S38-44.

5. Stephen R, Hongisto K, Solomon A, Lonnroos E. Physical activity and Alzheimer's disease: a systematic review. J Gerontol A Biol Sci Med Sci. Jun 1 2017;72(6):733-739.

6. Blondell SJ, Hammersley-Mather R, Veerman JL. Does physical activity prevent cognitive decline and dementia?: A systematic review and meta-analysis of longitudinal studies. BMC Public Health. 2014;14:510.

7. Chen WW, Zhang X, Huang WJ. Role of physical exercise in Alzheimer's disease. Biomed Rep. 2016;4(4):403-407.

8. Hauer K, Schwenk M, Zieschang T, Essig M, Becker C, Oster P. Physical training improves motor performance in people with dementia: a randomized controlled trial. J Am Geriatr Soc. 2012;60(1):8-15.

9. Schwenk M, Zieschang T, Englert S, Grewal G, Najafi B, Hauer K. Improvements in gait characteristics after intensive resistance and functional training in people with dementia: a randomized controlled trial. BMC Geriatrics. 12 2014;14(1):73.

10. Garuffi M, Costa JL, Hernandez SS, et al. Effects of resistance training on the performance of activities of daily living in patients with Alzheimer's disease. Geriatr Gerontol Int. 2013;13(2):322-328.

11. Pitkala KH, Poysti MM, Laakkonen ML, et al. Effects of the Finnish Alzheimer disease exercise trial (FINALEX): a randomized controlled trial. JAMA Intern Med. 27 2013;173(10):894-901.

12. Steinberg M, Leoutsakos JM, Podewils LJ, Lyketsos CG. Evaluation of a home-based exercise program in the treatment of Alzheimer's disease: the Maximizing Independence in Dementia (MIND) study. Int J Geriatr Psychiatry. 2009;24(7):680-685.

13. Karssemeijer EGA, Aaronson JA, Bossers WJ, Smits T, Olde Rikkert MGM, Kessels RPC. Positive effects of combined cognitive and physical exercise training on cognitive function in older adults with mild cognitive impairment or dementia: A meta-analysis. Ageing Res Rev. 2017;40:75-83.

14. Gates N, Fiatarone Singh MA, Sachdev PS, Valenzuela M. The effect of exercise training on cognitive function in older adults with mild cognitive impairment: a meta-analysis of randomized controlled trials. Am J Geriatr Psychiatry. 2013;21(11):10861097.

15. Song D, Yu DSF, Li PWC, Lei Y. The effectiveness of physical exercise on cognitive and psychological outcomes in individuals with mild cognitive impairment: A systematic review and meta-analysis. Int J Nurs Stud. 2018;79:155-164.

16. Groot C, Hooghiemstra AM, Raijmakers PG, et al. The effect of physical activity on cognitive function in patients with dementia: A meta-analysis of randomized control trials. Ageing Res Rev. 2016;25:13-23.

17. Wang C, Yu JT, Wang HF, Tan CC, Meng XF, Tan L. Non-pharmacological interventions for patients with mild cognitive impairment: a meta-analysis of randomized controlled trials of cognition-based and exercise interventions. J Alzheimers Dis. 2014;42(2):663-678.

18. Ohman H, Savikko N, Strandberg TE, Pitkala KH. Effect of physical exercise on cognitive performance in older adults with mild cognitive impairment or dementia: a systematic review. Dement Geriatr Cogn Disord. 2014;38(5-6):347-365.

19. Moher D, Liberati A, Tetzlaff J, Altman DG, Group P. Preferred reporting items for systematic reviews and meta-analyses: the PRISMA statement. PLoS Med. 2009;6(7):e1000097.

20. Roth M, Huppert FA, Mountjoy CQ, Tym E. CAMDEX-R:The Cambridge Examination for Mental Disorders of the Elderly. Cambridge: Cambridge University Press; 1998.

21. Folstein MF, Robins LN, Helzer JE. The mini-mental state examination. Archives of General Psychiatry. 1983;40(7):812-812.

22. Gil R, Toullat G, Pluchon $C$, et al. Une méthode d'évaluation rapide des fonctions cognitives (ERFC), son application à la démence sénile de type Alzheimer. Semin Hop Paris. 1986;62:2127-2133.

23. Mohs RC, Knopman D, Petersen RC, et al. Development of cognitive instruments for use in clinical trials of antidementia drugs: additions to the Alzheimer's disease assessment scale that broaden its scope. the Alzheimer's disease cooperative study. Alzheimer Dis Assoc Disord. 1997;11 Suppl 2:S13-21. 
24. Nasreddine ZS, Phillips NA, Bedirian V, et al. The Montreal Cognitive Assessment, MoCA: a brief screening tool for mild cognitive impairment. J Am Geriatr Soc. 2005;53(4):695-699.

25. Maher CG, Sherrington C, Herbert RD, Moseley AM, Elkins M. Reliability of the PEDro scale for rating quality of randomized controlled trials. Phys Ther. 2003;83(8):713-721.

26. Tombaugh TN, Mclntyre NJ. The mini-mental state examination: a comprehensive review. J Am Geriatr Soc. 1992;40(9):922-935.

27. Borenstein M, Hedges LV, Higgins JP, Rothstein HR. A basic introduction to fixed-effect and random-effects models for metaanalysis. Res Synth Methods. 2010;1(2):97-111.

28. Higgins JP, Thompson SG, Deeks JJ, Altman DG. Measuring inconsistency in meta-analyses. BMJ. 6 2003;327(7414):557-560.

29. Vreugdenhil A, Cannell J, Davies A, Razay G. A community-based exercise programme to improve functional ability in people with Alzheimer's disease: a randomized controlled trial. Scand J Caring Sci. 2012;26(1):12-19.

30. Arcoverde C, Deslandes A, Moraes $\mathrm{H}$, et al. Treadmill training as an augmentation treatment for Alzheimer's disease: a pilot randomized controlled study. Arq Neuropsiquiatr. 2014;72(3):190-196.

31. Bademli K, Lok N, Canbaz M, Lok S. Effects of physical activity program on cognitive function and sleep quality in elderly with mild cognitive impairment: A randomized controlled trial. Perspect Psychiatr Care. 2018. [Epub ahead of print]

32. Bossers WJ, van der Woude LH, Boersma F, Hortobagyi T, Scherder EJ, van Heuvelen MJ. A 9-Week aerobic and strength training program improves cognitive and motor function in patients with dementia: a randomized, controlled trial. Am J Geriatr Psychiatry. 2015;23(11):1106-1116.

33. Burgener SC, Yang Y, Gilbert R, Marsh-Yant S. The effects of a multimodal intervention on outcomes of persons with early-stage dementia. Am J Alzheimers Dis Other Demen. 2008;23(4):382-394.

34. Cancela JM, Ayan C, Varela S, Seijo M. Effects of a long-term aerobic exercise intervention on institutionalized patients with dementia. J Sci Med Sport. 2016;19(4):293-298.

35. Holthoff VA, Marschner K, Scharf M, et al. Effects of physical activity training in patients with Alzheimer's dementia: results of a pilot RCT study. PLoS One. 2015;10(4):e0121478.

36. Hong SG, Kim JH, Jun TW. Effects of 12-week resistance exercise on electroencephalogram patterns and cognitive function in the elderly with mild cognitive impairment: a randomized controlled trial. Clin J Sport Med. Nov 2018;28(6):500-508.

37. Christofoletti G, Oliani MM, Gobbi S, Stella F, Bucken Gobbi LT, Renato Canineu P. A controlled clinical trial on the effects of motor intervention on balance and cognition in institutionalized elderly patients with dementia. Clin Rehabil. 2008;22(7):618-626.

38. Kemoun $\mathrm{G}$, Thibaud $\mathrm{M}$, Roumagne $\mathrm{N}$, et al. Effects of a physical training programme on cognitive function and walking efficiency in elderly persons with dementia. Dement Geriatr Cogn Disord. 2010;29(2):109-114.

39. Kwak YS, Um SY, Son TG, Kim DJ. Effect of regular exercise on senile dementia patients. Int J Sports Med. 2008;29(6):471-474.

40. Lam LC, Chan WC, Leung T, Fung AW, Leung EM. Would older adults with mild cognitive impairment adhere to and benefit from a structured lifestyle activity intervention to enhance cognition?: a cluster randomized controlled trial. PLoS One. 2015;10(3):e0118173.

41. Lamb SE, Sheehan B, Atherton N, et al. Dementia and physical activity (DAPA) trial of moderate to high intensity exercise training for people with dementia: randomised controlled trial. BMJ. 2018;16(361).

42. Langoni CDS, Resende TL, Barcellos AB, et al. Effect of exercise on cognition, conditioning, muscle endurance, and balance in older adults with mild cognitive impairment: a randomized controlled trial. J Geriatr Phys Ther. 2019;42(2):E15-E22.

43. Lautenschlager NT, Cox KL, Flicker L, et al. Effect of physical activity on cognitive function in older adults at risk for Alzheimer disease: a randomized trial. JAMA. 2009;301(3):276-276.

44. Miu D, Szeto SL, Mak YF. A randomised controlled trial on the effect of exercise on physical, cognitive and affective function in dementia subjects. Asian J Gerontol Geriatr. 2008;3:8-19.

45. Muscari A, Giannoni C, Pierpaoli L, et al. Chronic endurance exercise training prevents aging-related cognitive decline in healthy older adults: a randomized controlled trial. Int J Geriatr Psychiatry. 2010;25(10):1055-1064.

46. Shimada H, Makizako H, Doi T, et al. Effects of combined physical and cognitive exercises on cognition and mobility in patients with mild cognitive impairment: a randomized clinical trial. J Am Med Dir Assoc. 2018;19(7):584-591.

47. Suzuki T, Shimada H, Makizako H, et al. A randomized controlled trial of multicomponent exercise in older adults with mild cognitive impairment. PLoS One. 2013;8(4):e61483.

Page 15/18 
48. Suzuki T, Shimada H, Makizako $H$, et al. Effects of multicomponent exercise on cognitive function in older adults with amnestic mild cognitive impairment: a randomized controlled trial. BMC Neurol. Oct 31 2012;12:128.

49. Toots A, Littbrand H, Bostrom G, et al. Effects of Exercise on Cognitive Function in Older People with Dementia: A Randomized Controlled Trial. J Alzheimers Dis. 2017;60(1):323-332.

50. Van de Winckel A, Feys H, De Weerdt W, Dom R. Cognitive and behavioural effects of music-based exercises in patients with dementia. Clin Rehabil. 2004;18(3):253-260.

51. Varela S, Ayan C, Cancela JM, Martin V. Effects of two different intensities of aerobic exercise on elderly people with mild cognitive impairment: a randomized pilot study. Clin Rehabil. 2012;26(5):442-450.

52. Venturelli M, Scarsini R, Schena F. Six-month walking program changes cognitive and ADL performance in patients with Alzheimer. Am J Alzheimers Dis Other Demen. 2011;26(5):381-388.

53. Williamson JD, Espeland M, Kritchevsky SB, et al. Changes in cognitive function in a randomized trial of physical activity: results of the lifestyle interventions and independence for elders pilot study. J Gerontol A Biol Sci Med Sci. 2009;64(6):688-694.

54. Yang SY, Shan CL, Qing H, et al. The effects of aerobic exercise on cognitive function of Alzheimer's disease patients. CNS Neurol Disord Drug Targets. 2015;14(10):1292-1297.

55. Harada CN, Natelson Love MC, Triebel KL. Normal cognitive aging. Clin Geriatr Med. 2013;29(4):737-752.

56. Black JE, Isaacs KR, Anderson BJ, Alcantara AA, Greenough WT. Learning causes synaptogenesis, whereas motor activity causes angiogenesis, in cerebellar cortex of adult rats. Proc Natl Acad Sci U S A. 1990;87(14):5568-5572.

57. Fordyce DE, Farrar RP. Enhancement of spatial learning in F344 rats by physical activity and related learning-associated alterations in hippocampal and cortical cholinergic functioning. Behav Brain Res. 1991;46(2):123-133.

58. Isaacs KR, Anderson BJ, Alcantara AA, Black JE, Greenough WT. Exercise and the brain: angiogenesis in the adult rat cerebellum after vigorous physical activity and motor skill learning. J Cereb Blood Flow Metab. 1992;12(1):110-119.

59. Um HS, Kang EB, Leem YH, et al. Exercise training acts as a therapeutic strategy for reduction of the pathogenic phenotypes for Alzheimer's disease in an NSE/APPsw-transgenic model. Int J Mol Med. 2008;22(4):529-539.

60. Baker LD, Frank LL, Foster-Schubert K, et al. Effects of aerobic exercise on mild cognitive impairment: a controlled trial. Arch Neurol. 2010;67(1):71-79.

61. Chene G, Beiser A, Au R, et al. Gender and incidence of dementia in the Framingham Heart Study from mid-adult life. Alzheimers Dement. 2015;11(3):310-320.

62. Snyder HM, Asthana S, Bain L, et al. Sex biology contributions to vulnerability to Alzheimer's disease: A think tank convened by the Women's Alzheimer's Research Initiative. Alzheimers Dement. 2016;12(11):1186-1196.

63. Koran MEI, Wagener M, Hohman TJ, Alzheimer's Neuroimaging I. Sex differences in the association between AD biomarkers and cognitive decline. Brain Imaging Behav. 2017;11(1):205-213.

64. Samaras T, Marson S, Lillis J. The close inverse relationship between male and female height and life expectancy. Innov Aging. 2018;2(Issue suppl_1):888 - 889.

65. Kolip P, Lange C. Gender inequality and the gender gap in life expectancy in the European Union. Eur J Public Health. 2018;28(5):869-872.

66. Aartolahti E, Tolppanen AM, Lonnroos E, Hartikainen S, Hakkinen A. Health condition and physical function as predictors of adherence in long-term strength and balance training among community-dwelling older adults. Arch Gerontol Geriatr.

2015;61(3):452-457.

\section{Figures}




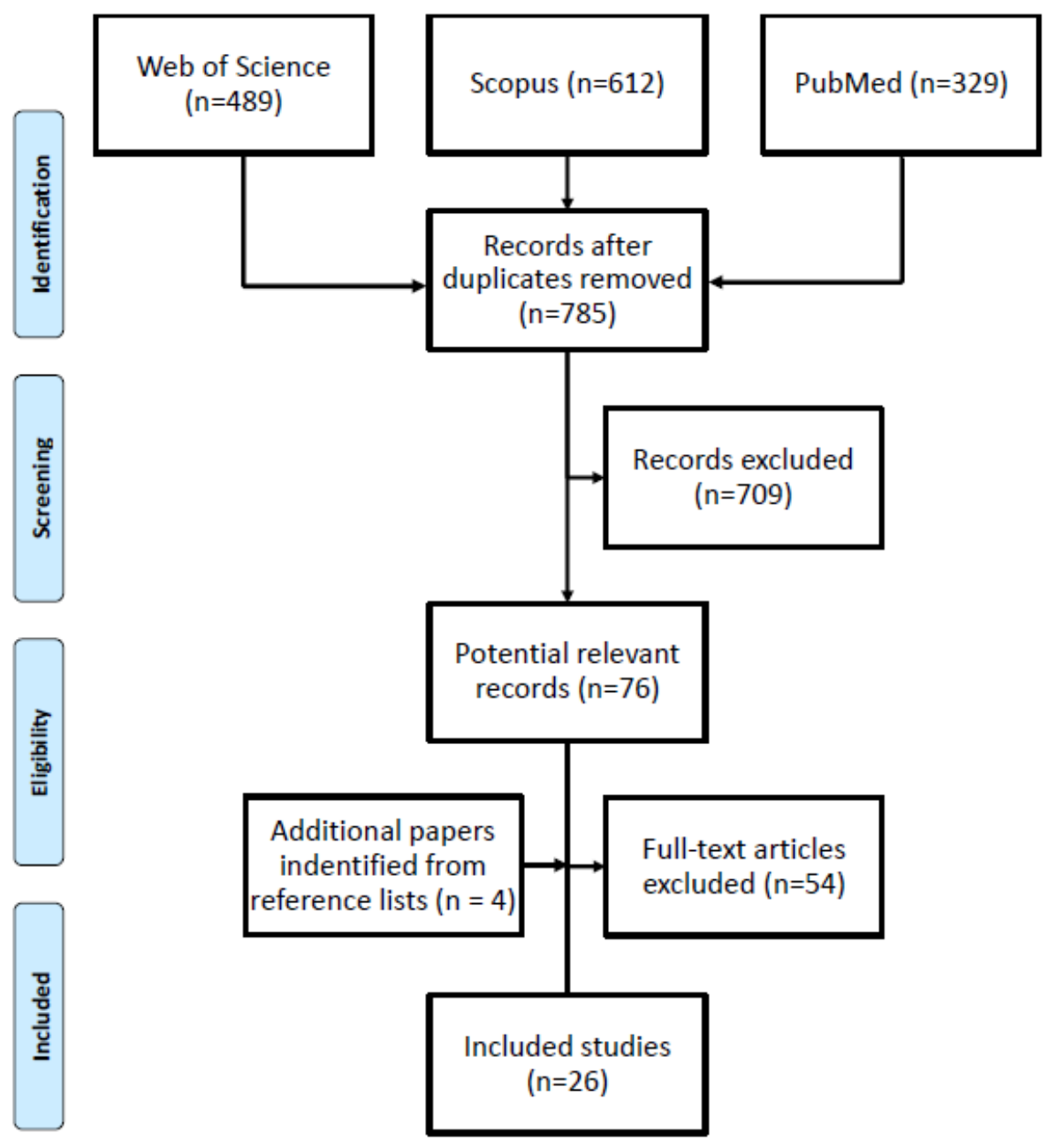

\section{Figure 1}

Flowchart illustrating the different phases of the search and study selection 


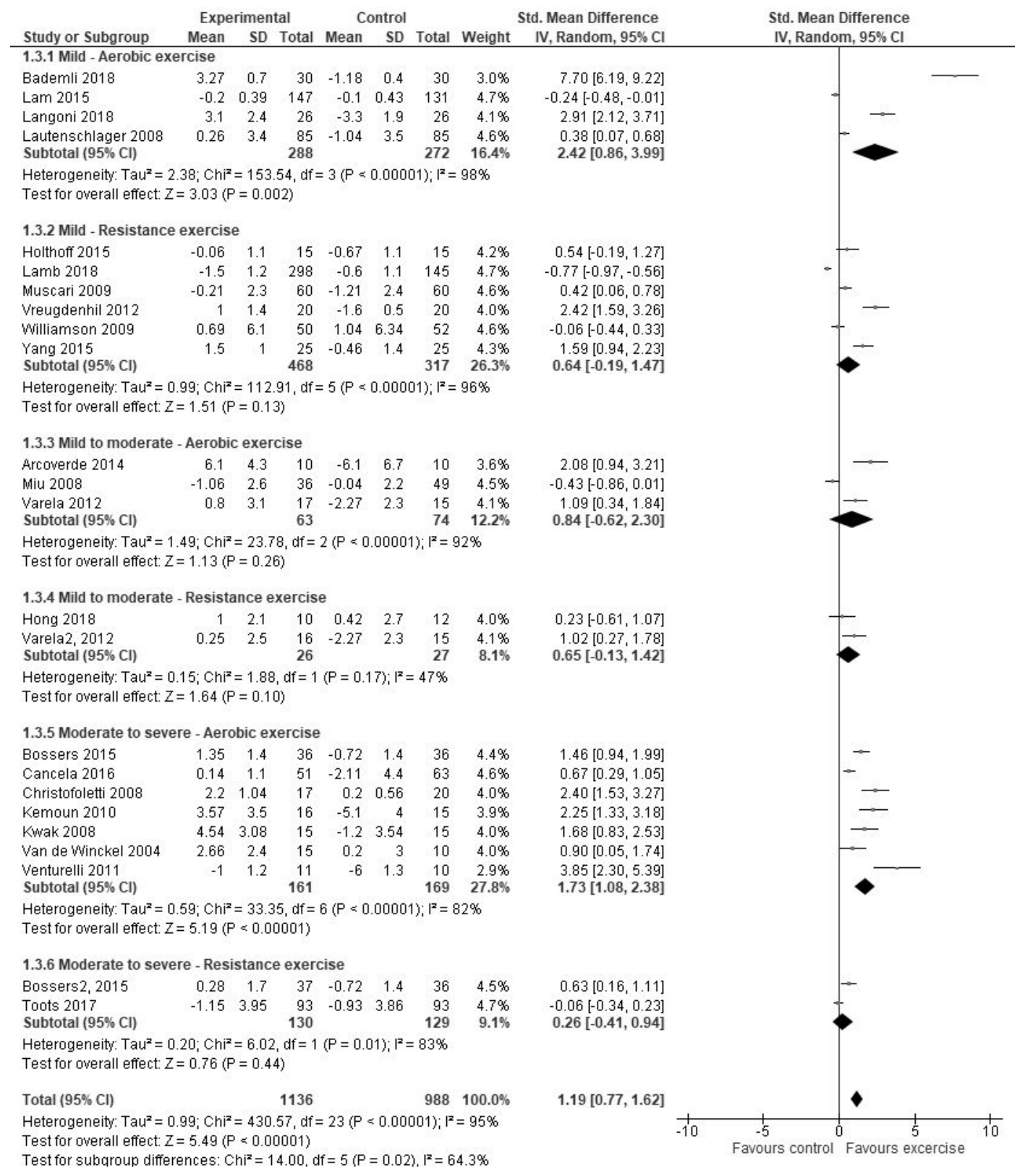

\section{Figure 2}

Effects meta-analysis of physical activities on cognitive function in people divided according to their cognitive impairment severity 